\title{
Analisis Ketahanan Usaha Pengolahan Petis Ikan Sebelum Dan Selama Masa Pandemi Covid-19 Di Desa Prenduan Kecamatan Pragaan Kabupaten Sumenep
}

\author{
Amilia Silfa Istiqhfariyah, Hapsari Wiji Utami
}

Universitas Islam Negeri Sunan Ampel Surabaya

ameliasilva195@gmail.com,wijiutamihapsari@uinsa.ac.id

\begin{tabular}{l}
\hline \hline Article Info \\
\hline Article history: \\
Published: Dec 28,2021 \\
Page: 49-57 \\
\hline Keyword: Mroduk Domestik \\
Regional Bruto (PDRB), \\
Upah Minimum \\
Kabupaten/Kota, dan \\
Tingkat Pengangguran \\
Terbuka.
\end{tabular}

\section{Abstract}

Penelitian ini bertujuan untuk mengetahui kondisi usaha pengolahan petis ikan sebelum dan selama pandemi covid-19, dan untuk mengetahui upaya yang dilakukan pengusaha petis ikan dalam bertahan pada masa pandemi covid-19. Salah satu cara berempati dan menjaga komunikasi dengan pelanggan, dengan kondisi saat ini sangat penting menjaga kesehatan, secara aktif dapat menginformasikan bahwa usaha petis ikan ini melakukan penerapan sesuai aturan pemerintah dengan mencegah virus penularan seperti penyemprotan disenfektan, pengecekan suhu pada tubuh pekerja. Hal ini dilakukan guna mempertahankan kepercayaan konsumen bahwa usaha petis ikan ini dapat dipasarkan seperti semula.

Kata kunci : Produk Domestik Regional Bruto (PDRB), Upah Minimum Kabupaten/Kota, dan Tingkat Pengangguran Terbuka

This study aims to determine the condition of the fish petis processing business before and during the covid-19 pandemic, and to find out the efforts made by fish petis entrepreneurs in surviving the covid-19 pandemic. One way to empathize and maintain communication with customers, with current conditions it is very important to maintain health, can actively inform that this fish petis business is implementing according to government regulations by preventing virus transmission such as spraying disinfectants, checking the body temperature of workers. This is done in order to maintain consumer confidence that this fish paste business can be marketed as before.

Keyword : Gross Regional Domestic Product (GRDP), Regency/City Minimum Wage, and Open Unemployment Rate

Copyright () 2021 OECONOMICUS Journal of Economics

\section{Pendahuluan}

Pragaan adalah sebuah kecamatan yang terletak di Kabupaten Sumenep. Salah satu kabupaten di Jawa Timur yang terletak di ujung timur Pulau Madura. Kabupaten Sumenep merupakan kabupaten yang memiliki potensi perikanan yang melimpah dan bisa dimanfaatkan. Apabila pengolahan bisa dimaksimalkan dan dikerjakan secara

\section{Editorial Office:}

Prodi Ilmu Ekonomi Fakultas Ekonomi dan Bisnis Islam, UIN Sunan Ampel Surabaya

Jl. Ahmad Yani 117 Surabaya, Jawa Timur 60237, Indonesia.

Email: oje@uinsby.ac.id 
professional maka bisa menunjang perekonomian masyarakat Kabupaten Sumenep. Dengan hasil perikanan yang melimpah di madura ini sangat disayangkan apabila tidak di olah dengan baik. Apabila sumber daya yang ada di produksi dengan baik maka akan bisa membantu perekonomian warga sekitar.

Sebagian besar warga di Kabupaten Sumenep terutama di Desa Prenduan bagian Pesisir mendapatkan pendapatan dari mencari ikan atau biasa disebut dengan nelayan. Hasil ikan yang didapatkan dari nelayan akan di olah agar bisa dijual. Salah satu hasil olahan ikan yang mejadi ciri khas Pulau Madura yaitu petis ikan. Di Desa Prenduan ada beberapa pengusaha petis ikan khas Madura adalah Ibu Bahriyah, Ibu Dayyanah dan Ibu Sakdiyah yang sama sama beralamat di desa Prenduan. Ibu Bahriyah adalah salah satu pengusaha petis yang tekenal di desanya, usaha beliau bertempat di selatan Polsek Prenduan. Ibu Bahriyah adalah pengelola petis tongkol sejak tahun 1980, sedangkan suaminya adalah seorang nelayan. Dalam sekali produksi Ibu Bahriyah membutuhkan modal awal kurang lebih sebesar Rp1.000,000 Untuk pembuatan petis biasanya membutuhkan bahan ikan sebanyak 3 kwintal dalam sekali produksinya. Produksi pembuatan petis dalam satu minggu bisa 2 kali produksi. Selain petis yang diolah tekenal enak, Ibu Bahriyah terkenal sebagai pengusaha yang sangat gigih dalam mengelola usahanya. Karena beliau memiliki keinginan membantu suaminya untuk menambah penghasilan. Selama usahanya berjalan beliau sudah memiliki 4 karyawan, seorang laki-laki dan 3 perempuan.

Ibu Dayyanah juga salah satu pengusaha petis yang memiliki keunggulan demikian, dan usahanya juga sudah berlangsung lama pula. Ikan yang digunakan untuk memproduksi petis tersebut juga menggunakan ikan tongkol. Usaha ibu Dayyanah berdiri sejak 2011. Untuk produksi petis ikan, pengusaha ini membutuhkan ikan tongkol sekitar 2 sampai 3 kwintal dalam sebulan penuh. Sedangkan usaha petis yang diproduksi ibu Sakdiyah ini baru berdiri sejak tahun 2017. Ikan yang digunakan untuk pembuatan petis ikan di olah dari ikan tongkol untuk produksinya di lakukan dengan cara tradisional. Ikan yang digunakan untuk pembuatan petis menghabiskan $3 \mathrm{~kg}$ saja karena termasuk pengusaha yang baru merintis usaha. Ikan tongkol di dapatkan dari hasil tangkapan suaminya, yang merupakan seorang nelayan. Selain berjualan dan memproduksi petis, beliau juga menjual ikan hasil tangkapan suaminya.

Masyarakat Indonesia sangat minat terhadap produksi petis ikan ini karena mempunyai keunggulan dalam hal rasa, salah satunya adalah petis ikan yang terbuat dari bahan dasar kaldu ikan. Petis Madura ini merupakan kuliner khas yang biasanya di jadikan bahan rujak yang memiliki rasa gurih, d a n rasa gurihnya dihasilkan dari sari rebusan ikan yang merupakan bahan utama pembuatan petis. Namun petis ini berbeda dengan petis diluar Madura yang menggunakan bahan udang sehingga memiliki rasa manis. Petis ikanMadura yang terkenal enak adalah petis dari Sumenep karena petis ini terbuat dari tongkol khas pantai utara yang terkenal atas kualitasnya, hal ini yang membedakan dengan petis diluar Kabupaten Sumenep (Pamekasan, Sampang atau Bangkalan).

Teknik pengolahan petis ikan sendiri sangat simpel. Ikan yang di pakai untuk membuat petis adalah hasil dari tangkapan nelayan langsung. Setelah petis telah di olah maka hal selanjutnya adalah menjualkannya. Pemasaran petis ini sudah sangat luas di Pulau Jawa maupun di luar Jawa. Kebutuhan manusia dan sosial adalah identifikasi dalam memenuhi inti dari pemasaran. Salah satu definisi singkat dari pemasaran adalah memenuhi kebutuhan dengan cara yang menguntungkan. 
Dampak dari penjualan petis Madura pada masa pandemi covid-19 menurun yang menyebabkan pendapatan usaha di bidang petis Madura ini menurun juga. Hal ini berpengaruh yang disebabkan banyak wisatawan yang sudah jarang berkunjung ke Pulau Madura, yang menyebabkan pemasarannya kurang maksimal.

Sedangkan dari pemerintah juga menerapkan pembatasan masyarakat dalam melakukan perjalanan antar kota maupun ke Luar Negeri. Hal ini sangat beresiko dalam pemasaran petis yang sudah menjadi ciri khas Madura. Pada awalnya petis Madura sangat laris dipasaran menjadi penurun untuk penjualannya. Sebelum covid-19 menyebar pendapatan usaha petis ikan untuk sekali produksi bisa mencapai 2 juta, semenjak adanya pandemi covid-19 ini pendapatan petis mulai menurun yang diakibatkan adanya pandemi. Hal tersebut sangat berpengaruh pada pendapatan usaha pengolahan petis yang ada di pulau Madura. Pada sebelum pandemi covid-19 pemilik usaha petis ikan bisa mengelola dan mengolah petis sebanyak dua atau tiga kali dalam waktu seminggu, sedangkan setelah pandemi covid-19 pengolahan petis hanya bisa dilakukan satu kali dalam satu minggu. Untuk faktor lainnya tidak terpengaruh dengan adanya pandemi covid-19.

\section{Kajian Pustaka \\ Strategi Ketahanan Usaha}

Strategi merupakan sejumlah tindakan yang terintegrasi dan terkoordinasi yang diambil unutk mendaya gunakan kompetensi inti serta memperoleh keuntungan bersaing.

Keberhasilan suatu perusahaan, sebagaimana diukur dengan daya saing strategis dan profitabilitas tinggi, merupakan fungsi kemampuan perusahaan dalam mengembangkan dan menggunakan kompetensi inti baru lebih cepat daripada usaha pesaing untuk meniru keuntungan yang ada saat ini.

Kebertahanan dalam bahasa inggrisnya disebut dengan resilience. Istilah resilience pertama kali digunakan dalam ilmu fisika untuk menunjukkan perilaku (gaya) pegas atau daya kenyal. Namun pada era 1970-an. Kebertahanan (resilience) diadopsi oleh masyarakat untuk menggambarkan fenomena yang agak berbeda. Kebertahanan menurut Muller adalah kemampuan sistem, komunitas atau masyarakat tekena tehadap bahaya untuk menahan, menyerap, mengakomodasi dan memulihkan dari efek bahaya secara tepat waktu dan cara efisien, temasuk melalui cara pelestarian dan pemulihan yang penting dasar struktur dan fungsi.

Strategi bertahan ditetapkan oleh perusahaan terkait erat dengan kemampuan bertahan perusahaan. Kemampuan bertahan lebih di miliki oleh industri kecil menengah karena sifat bisnis itu sendiri yang langsung di menejemeni oleh para pemiliknya sehingga fleksibel dalam beradaptasi terhadap perubahan lingkungan dan mempunyai kecepatan secara tekad.

Industri kecil diuntungkan oleh kondisi geografis, yang membuat produk produk industri kecil memperoleh proteksi alami karena pasar yang dilayani terjangkau oleh inovasi produk - produk skala besar. Oleh karena itu perkembangan industri rumah tangga memegang peranan penting dalam perkembangan ekonomi.

Setiap perusahaan mempunyai tujuan untuk dapat tetap hidup dan berkembang tujuan tersebut hanya dapat dicapai melalui usaha mempertahankan dan meningkatkan penjualannya, melalui usaha mencari dan membina langganannya, serta usaha menguasai pasar. Tujuan ini hanya dapat dicapai apabila bagian pemasaran perusahaan melakukan strategi yang mantap untuk dapat menggunakan kesempatan atau peluang yang ada dalam pemasaran, sehingga posisi atau kedudukan perusahaan dipasar dapat dipertahankan dan ditingkatkan.

Strategi pemasaran mempunyai peranan yang sangat penting untuk 
keberhasilan usaha perusahan umumnya dan dibidang pemasaran khususnya.

\section{Pengolahan Petis Ikan di Desa Prenduan Kecamatan Pragaan Kabupaten Sumenep Sebelum dan Selama Masa Pandemi Covid-19}

Petis Madura bisa dibuat dari kaldu udang atau ikan yang dimasak hingga pekat. Biasanya menggunakan kaldu dari pembuatan pindang ikan. Ikan dengan taburan garam yang disusun berlapis ditemapan dimasak dengan api kecil. Saat matang, pindang pindang ditiriskan, sementara larutan kaldu ikan bercampur garam ditampung dan diolah menjadi petis ikan.

Petis Surabaya juga dibuat dari kaldu udang atau ikan. Tapi umunya petis Surabaya dibuat dari kepala ikan yang diblender dengan air, disaring. Kemudian dimasak bersama bumbu bumbu, gula dan garam hingga airnya menyusut menjadi pasta. Karena dasar cara pembuatannya berbeda itulah maka rasa petis Madura dengan petis Surabaya juga berbeda. Petis adalah komponen dalam masakan Indonesia yang dibut dari produk sampingan pengolahan makanan berkuah yang dipanaskan hingga cairan kuah menjadi kental seperti saus yang lebih padat.

Petis terbuat dari ikan, kupang dan udang bahkan dari daging sapi atau petis sapi. Petis ini masih termasuk atau tergolong bumbu penyedap rasa aneka masakan dan makanan di Indonesia sama halnya dengan terasi yang dapat melezatkan berbagai masakan tradisional Nusantara khususnya petis ini lebih dikenal di Pulau Jawa dan Bali.

Petis adalah masakanan Indonesia yang dibuat dari produk sampingan dari rebusan ikan yang dijual matang dalam jumlah besar (biasanya dari ikan pindang, kupan atau udang) cairan sisa perebusan ikan dipanasi hingga cairan kuah menjadi kental seperti saus yang lebih padat. Dalam pengolah selanjutnya, petis ditambah gula batok. Ini menyebabkan warnanya menjadi cokelat pekat cenderung hitam dan rasanya manis. Petis udang dikenal sebagai masakan khas Sidoarjo, sedangkan Madura paling terkenal enak.

Berbeda dengan terasi yang dikenal dan dikonsumsi oleh penduduk Asia Tenggara umumnya, petis nampaknya hanya dikenal di Indonesia. Hampir semua segara di Asia Tenggara, seperti Indonesia, Malaysia, Singapura, Thailand, Vietnam, Filipina mengenal terasi dengan variasi bentuk sediaan kering, basah, atau setengah basah dan nama. Namun aroma yang keluar dari terasi hasil olahan Negara Negara tersebut sama. Petis biasa dipakai sebagai penyedap pada beberapa makanan seperti rujak (cingur, gobet, manis) kupang lontong (Sidoarjo) semanggi (Surabaya) tahu tek (Lamongan) atau campor (Madura). Tahu petis aatau petis tahu di Surabaya termasuk hidangan yang paling favorit, kupang tahu petis singaparna Bandung, telur cit bumbu khas Banyuwangi. Petis Madura sendiri memiliki keunikan dari petis lainnya yaitu memiliki ciri khas tersendiri, ciri khasnya adalah rasanya cenderung asin, mempunyai tampilan yang cenderung cerah dan warnanya lebih merah kecoklatan. Madura merupakan salah satu pulau penghasil petis yang cukup terkenal. Bahan pangan yang biasa dijadikan sebagai bumbu rujak ini di produksi di beberapa tempat.

Petis adalah semacam saus khas Indonesia dari wilayah Jawa Timur yang menonjolkan rasa dan aroma udang. Meskipun petis menonjolkan rasa dan aroma udang tetapi sesungguhnya petis merupakan hasil sampingan pengolahan tak melulu dari udang tetapi juga bisa dibuat dari kupang dan ikan lainnya. Bahkan di Boyolali, Jawa Tengah terdapat petis tetapi berasal dari hasil sampingan olahan sapi. Petis rujakan di Jawa Timur biasanya dipakai untuk campuran makanan makanan tradisional, seperti rujak cingur, kupang, semanggi lontong balap, tahu campur dan tahu tek, sedangkan petis hitam biasanya diperlukan 
sebagai saus khususnya untuk tahu goreng. Petis rujakan bisa dibuat dengan cara yang amat sangat sederhana dengan bahan baku yang gampang didapat yaitu dengan merebus kulit atau kepala udang bahkan dalam keadaan darurat, seperti diluar negeri, petis rukan bisa dibuat dengan terasi.

Petis ikan di Desa Prenduan Kecamatan Pragaan Kabupaten Sumenep yang dimiliki oleh ibu bahriyah, ibu Dayyanah dan ibu Sakdiyah. Untuk karyawan yang bekerja didominasi oleh pekerja wanita, itu menunjukkan bahwa karakter wanita lebih tekun dan teliti serta memiliki loyalitas tinggi, serta mempunyai sikap patuh, mudah diatur dan tidak banyak menuntut. Adapun visi dan misinya tak sama lain adalah menjadikan petis ikan sebagai produk yang dicintai masyarakat. Sedangkan untuk misinya adalah menghasilkan produk makanan khas Madura dengan menciptakan produk yang baik. Untuk tujuan dari petis ikan ini adalah menampilkan produk petis ikan yang lebih menarik dan membuat makanan lebih bermanfaat.

\section{Metode Penelitian}

Metode penelitian yang digunakan adalah pendekatan kualitatif deskriptif dengan menggunakan sumber data primer dan sekunder. Data Primer didapat dari hasil wawancara dengan 3 pengusaha pengolahan petis ikan, sedangkan data sekunder didapat dari beberapa literatur seperti jurnal, buku, skripsi dan website lainnya yang berhubungan dengan penelitian.

Hasil dari penelitian bisa diambil dari beberapa wawancara yang telah di lakukan dengan pemilik dan karyawan yang ada. Bahwa petis ikan akan tetap berproduksi karena tidak ingin pelanggan tetap pindah ke pengusaha lain dan masih ingin melanjutkan usaha yang telah berdiri sejak lama. Dan upaya yang dilakukan Ibu Bahriyah adalah tetap mengolah ikan tetapi bukan hanya di olah menjadi petis ikan melainkan mengolah ikan dengan cara di asinkan. Upaya yang dilakukan Ibu Dayyanah yakni menambah skill pemasaran secara online dan memberikan promo ke pembeli. Dan pada usaha Ibu Sakdiyah dengan upaya memberikan promosi diatas pembelian maksimal dan juga menjualkan di toko - toko terdekat.

Untuk bertahan dalam masa pandemi covid 19 ada beberapa cara yang dilakukan oleh beberapa pengusaha petis ikan di sumenep. Sebagai sampel kebertahanan usaha petis ikan di Kabupaten Sumenep, ada 3 pengusaha petis yang di wawancara. Berikut hasil yang diperoleh dalam penelitian dan wawancara langsung ke 3 pengusaha petis ikan.

Berdasarkan hasil wawancara yang telah dilakukan oleh ibu Bahriyah dan menyatakan bahwa usaha petis ikan yang sudah di geluti ini telah memberikan lowongan pekerjaan kepada beberapa orang yang telah membutuhkan. Hal tersebut menjadi semangat mereka agar tetap melestarikan khas petis yang ada di Madura. Cara yang dilakukan oleh pemilik dan karyawan untuk tetap eksis dalam berdagang dan memproduksi petis, dan akan tetap berusaha agar petis yang di hasilkan menjadi petis unggulan, selain itu cara agar tetap bertahan dalam masa pandemic seperti ini adalah tetap memproduksi petis, menjualkan kepada pelanggan setia, menjualkan ke pecinta petis luar kota dan kepada masyarakat sekitar. Selain memprosukdi petis pemilik dan karyawan mengolah sisa ikan sebagai ikan asin dan dijualkan agar modal yang telah di pakai bisa kembali dan tetap mendapatkan laba.

Berdasarkan hasil wawancara dengan pengusaha kedua yaitu ibu dayyanah menyatakan bahwa kondisi usaha petis ikan yang dijalani sama seperti pengusaha pertama, untuk pengolahan petisnya juga dengan cara tradisional. Untuk usaha petis ikanini hanya di jualkan di lokas saja yaitu di kota Madura. Untuk meminimalisir kerugian akibat dampak pandemi. Pengusaha memiliki inisiatif untuk 
pemasaran via online dan offline. Untuk online di kerjakan oleh beberapa karyawan yang melek akan kecanggihan tekhnologi dan penjualan offline di jualkan ke beberapa pelanggan setia yang akan di pasarkan lagi. Untuk hambatan sendiri yaitu pelanggan petis ikan lebih tertarik untuk interaksi langsung dengan produsen. Sedangkan pada saat pandemi seperti ini tidak memungkinkan untuk berkerumun, jadi pendapatan kami menurun. Pada awal mulanya pendapatan bisa mencapai 2 juta dalam sekali produksi.

Berdasarkan hasil wawancara oleh ibu sakdiyah mendapatkan hasil yaitu usaha petis ikan ini berbeda dengan usaha petis pertama dan kedua, karena ibu sakdiyah tergolong pengusaha petis yang pada saat ini masih merintis. Bahan baku yang digunakan tidak mengeluarkan banyak modal karena ikan di peroleh langsung oleh suaminya yang termasuk nelayan. Pengolahan juga di lakukan dengan cara tradisional, pemasaran masih dilingkungan kota saja karena tergolong produsen petis ikan yang baru memulai usaha. Petis ikan ibu sakdiyah merupakan petis unggulan walaupun baru berdiri. Keunggulan yang dimiliki oleh produsen ini adalam bisa memenajemen sendiri. Kesulitan yang dialami adalah pemesaran apalagi pada masa pandemi seperti ini. Untuk upaya yang dilakukan untuk tetap bertahan dalam usahanya adalah dengan memberikan promosi kepada penjual petis ikan yang ada di Desa Prenduan agar petis ikan tetap laku dan tidak menimbukan kerugian bagi produsen.

\section{Pembahasan}

\section{Analisis kondisi usaha pengolahan petis ikan sebelum dan selama pandemi covid- 19}

Pengolahan petis ikan merupakan salah satu pekerjaan yang banyak di lakoni oleh warga Madura. Usaha petis ikan ini digeluti oleh beberapa pengolah yang ada di daerah Madura, khususnya di Desa Prenduan Kecamatan Pragaan Kabupaten
Sumenep. Ada beberapa produsen petis ikan dan pelaku usaha petis yang sangat terkenal, tidak sedikit pelaku usaha petis ikan yang mengambil petis ikan di beberapa pengusaha petis yang ada di Desa Prenduan. Ada beberapa usaha yang memang turun menurun, dari nenek moyangnya, serta ada juga yang memang baru merintis usahanya. Ada 3 pengusaha petis ikan yang terkenal di Desa Prenduan, yang mana memang petis ikan yang dihasilkan rasanya sangat enak. 3 produsen tersebut biasanya di panggil ibu Bahriyah, ibu dayyanah dan ibu sakdiyah, masing masing pengusaha memiliki karyawan.

Petis ikan ini bisa dibilang sebagai produk unggul karena bisa dilihat dari cara mengolahan dan bahan yang digunakan, serta banyaknya pedagang yang mengambil hasil olahan petis ikan yang di olah oleh usaha rumahan ibu bahriyah. Petis ikan yang diolah oleh ibu bahriyah dan beberapa karyawannya. Petis ikan ibu bahriyah ini merupakan olahan rumahan yang banyak digemari dan diminati oleh beberapa kalangan.

Pengolahan petis ini di ambilkan dari hasil nelayan disekitar rumahnya. Dan diolah tanpa menggunakan bahan pengawet dan murni dari sari ikan tongkol, serta tanpa bahan tambahan seperti tepung terigu. Untuk pengolahan petis ikan di tempat ibu bahriyah biasanya di lakukan selama persediaan sudah hampir habis, baru dilakukan produksi lagi, dan bahannya disesuaikan dengan hasil tangkapan selayan pada saat proses produksi.

Untuk proses pengolahannya diproduksi dengan kayu bakar, untuk langkah langkah pembuatannya yaitu dengan merebus ikan dari hasil tangkapan nelayan, setelah air rebusan mendidih dan mengeluarkan busa ikan yang digunakan diangkat dan ditiriskan, karena pada umumnya yang dibutuhkan air sari rebusan ikannya saja, yang kemudian hasil air sari ikan tersebut ditambahkan garam dan bumbu lainnya sehingga diaduh sampai 
mengental, diamkan agar tidak panas kemudian langkah terakhir yaitu pengepresan kedalam toples lalu siap untuk dipasarkan.

Untuk pemasaran petis ikan ibu Bahriyah ini hanya di jualkan kepada pelanggan tetap dan orang orang yang sudah menjadi pelanggan setia baik diluar Madura atau sekitar daerah yang siap untuk menjualkan produk petis ikan, karena terhalang pengetahuan tentang tekhnologi. Pemasaran yang di gunakan oleh ibu Dayyanah selain menjualkan kepada pelanggan dan juga dipasarkan di toko kelontong, ibu dayyanah menjualnya secara online, berhubung penghasilan yang didapatkan lebih banyak, karena terhalang oleh pandemi juga beliau membuat akses pemasaran secara online. Sedangkan ibu Sakdiyah berbeda dengan kedua pengusaha tersebut. Cara yang dilakukan hanya menjualkan ke sekeliling lokasi produksi petis ikan saja, karena memang usaha yang di kelola belum lama dirintis dengan itu masyarakata belum banyak yang mengenalnya.

Tabel 1

Data Pendapatan Usaha Pengolahan Petis Ikan tahun 2018 - 2021 Di Desa Prenduan Kecamatan Pragaan Kabupaten Sumenep

\begin{tabular}{|c|c|c|c|c|}
\hline Tahun & 2019 & 2020 & 2021 & $\begin{array}{c}\text { TOTAL } \\
\text { PENDAPATAI }\end{array}$ \\
\hline Usaha Ibu Bahrivah & $61,000,00$ & $41.795,00$ & $18,650,00$ & $121.45,00$ \\
\hline Usada bu Dayyanah & $55.550,00$ & $47,00,00$ & 12000,00 & $114,550,00$ \\
\hline Usaha Ibu Sakdivy & $45,000,00$ & $38.50,000$ & $5,350,00$ & $888.850,00$ \\
\hline
\end{tabular}

Dari data penyajian, usaha pengolahan petis ikan dalam kurun waktu 4 tahun, yakni mulai sejak tahun 2018 - 2021 pendapatan usaha petis tidak semua pengusaha merasakan dampak dari pandemic covid-19 ini, Dampak adanya pandemi covid-19 terhadap pengusaha petis ikan di Desa Prenduan Kecamatan Pragaan Kabupaten Sumenep merasakan menurunnya pendapatan disebabkan karena berbagai hal yang diakibatkan adanya penurunan daya minat masyarakat dan harga bahan baku mulai meningkat sehingga berpengaruh pada tingkat pendapatan. Pada tahun 2019 sebelum covid-19 pendapatan petis ikan memasuki tingkat daya jual bagus dan pendapatan juga maksimal. Usaha petis ikan ibu Bahriyah berdiri sejak 1980, sudah memiliki pelanggan tetap yang loyal. Petis ikan ini sangat dikenal oleh masyarakat. Menggunakan bahan baku yang berkualitas. Tanpa adanya pengawet, sangat menjaga cita rasa. Pendapatan atau omset yang diperoleh merosot dari sebelum adanya covid 19, yang mana awal mula mendapatkan keuntungan $40 \%$ sedangkan pada masa pandemi covid 19 mendapatkan keuntungan $25 \%$.

Dengan adanya covid-19 petis ikan banyak memiliki hambatan baik dalam hal pemasaran, bahan baku naik, dan proses pengiriman terbatasi maka dari itu mulai menurun minat masyarakat terhadap petis ikan. Bagi Ibu Dayyanah yang memulai usaha petis ikan sejak 2008 juga merasakan penurunan dengan tetap stabil karena barang dagangannya tetap terjual dengan proses pemasaran yang digunakan secraa online. Dengan pemasaran online tersebut Ibu Dayyanah yang mengupayakan agar usaha nya tetap bertahan yaitu dengan melakukan sistem pemasaran secara online dan juga berkolaborasi dengan toko kelontong yang siap membantu usaha beliau, karena dengan cara ini ibu Dayyanah dapat meningkatkan hasil pendapatan serta usaha petis ikan tidak tertutup. Pendapatan yang dimiliki Ibu Sakdiyah juga kurang maksimal pada dasarnya usaha tersebut kurang banyak diminati masyarakat kalangan luar jawa, melainkan dipasarkan hanya di kalangan desa tersebut.

\section{Upaya Mempertahankan Usaha Petis Ikan di Masa Pandemi Covid-19}


Awal mula adanya covid 19 pemilik usaha petis ikan merasa biasa tanpa ada kekhawatiran, tidak ada penurunan omset atau penurunan untuk produksi dan pemasarannya, karena efek dari daerah yang kecil tidak seluas Surabaya dan Jakarta yang harus menerapkan PSSB. Tetapi sampai saat ini covid 19 belum bisa terselesaikan, dan saya sekarang merasa ada dampak penurunan terhadap pendapatan karena adanya batasan pengiriman barang keluar negeri atau lokal.

Untuk tetap bertahan di masa pandemic covid 19 pengusaha petis tetap menjalankan usahanya. Dengan cara tetap memproduksi petis ikan yang berkualitas, menambah skill dalam penjualan online agar tetap ada pemasukan, tetap menjualkan ke pelanggan yang memang menjualkan produk di pasar, menjualkan ke luar kota. Selain memproduksi petis ikan, salah satu pengusaha ada juga yang memilih untuk memproduksi ikan asin sisa dari produksi petis ikan, dan tentunya ikan asin yang berkualitas. Hal tersebut semata dilakukan agar pengusaha tetap bisa menjalankan bisnis dan tetap bisa melestarikan petis ikan.

Berdasarkan hasil wawancara dari pemilik usaha petis Ibu Dayyanah pada masa pandemi covid 19 bahwa usaha petis ikan akan tetap bertahan walau pada masa pandemi covid 19 seperti ini karena tidak mau kalau karyawan saya berhenti bekerja, karena mereka sangat bergantung dengan penghasilan yang didapatkan dari sini, dari sisi lain juga tidak ingin usaha ini berhenti karena usaha ini sudah berdiri lama dan sudah turun temurun.

Upaya untuk tetap bertahan yaitu dengan tetap produksi petis ikan kalau petis ikan lama dalam proses penjualannya, dan berfikir untuk mengeringkan ikan yaitu membuat ikan asin dan dijualkan untuk meminimalisir kerugian yang nantinya akan didapatkan.

Selain hasil dari wawancara dengan pemilik, Ibu Bahriyah juga menambahkan bahwa : "Selama bekerja, saat ini lah seharusnya saya benar benar bekerja keras agar usaha petis ini tidak berhenti karena adanya dampak covid 19. Saya berusaha keras untuk tetap mengolah petis agar tetap di gemari oleh banyak kalangan. Dan saya juga mengolah ikan asin, untuk upaya agar meminim kerugian yang akan di dapat"

Selain itu juga ada beberapa karyawan yang bekerja di Usaha Ibu Bahriyah mengatakan bahwa : Petis ikan adalah ciri khas dari Madura tidak semudah itu untuk merelakan petis ikan ini merugi. Untuk upaya yang dilakukan dan sesuai dengan intruksi dari pemilik, kami akan tetap memproduksi dan menjualkannya. Kalaupun petis masih banyak stoknya kami akan mengolah ikan dengan cara lain, yaitu dengan mengeringkan atau mengasinkannya. Agar usaha tidak merugi banyak.

Hasil wawancara dengan pengusaha petis ibu dayyanah menyatakan bahwa : "Selama saya menjalankan usaha petis ikan, saya tetap konsisten bahwa memang sampai kapanpun saya akan tetap melestarikan petis ikan khas Madura. Walaupun masa pandemi ini membuat saya sedikit kesulitan untuk produksi dan berjualan. Saya akan berusaha semaksimal mungkin untuk menjualkan petis ikan, cara yang saya lakukan yaitu menambah skill dalam berjualan online, karena memang saat ini berjualan secara offline sangat berpengaruh. Selain itu pula saya tetap akan memberikan kualitas terbaik dalam memproduksi petis ikan".

Hasil wawancara dengan ibu sakdiyah yang memiliki usaha petis juga, beliau mengucapkan bahwa :

"Saat seperti ini membuat saya sedikit terpuruk, karena memang petis ikan saya ini masih tergolong baru dan masih sedikit pelanggan. Tetapi saya tetap berusaha untuk menjualkan ke toko kelontong, dan saya berusaha untuk memberikan promosi, agar petis ikan saya tetap terjual. Dan saya yakin walaupun petis ikan saya ini merupakan produsen baru tetapi untuk kualitas tidak 
kalah jauh dengan produsen yang sudah berpuluh puluh tahun".

\section{Kesimpulan}

Secara keseluruhan "Analisis Ketahanan Usaha Pengolahan Petis Ikan Sebelum dan Selama Masa Pandemi Covid19 Di Desa Prenduan Kecamatan Pragaan Kabupaten Sumenep" dapat disimpulkan bahwa :

(1) Sebelum adanya pandemi covid 19 produsen petis ikan di Desa Prenduan yaitu ibu Bahriyah dan ibu Dayyanah memproduksi petis bisa 3 kali dalam seminggu dengan jumlah yang banyak, akan tetapi berbeda dengan ibu Sakdiyah karena memang petis ikannya tergolong baru. Sedangkan pada masa pandemi covid-19 ketiga produsen petis ikan ini memproduksi apabila ada pesanan saja.

(2) Upaya yang dilakukan untuk meminimalisir kerugian petis ikan, Pengusaha Petis ikan memproduksi ikan asin agar ikan yang awalnya di gunakan untuk petis tidak terbuang, dengan begitu pengusaha dapat mendapatkan penghasilan tambahan dengan membuka usaha ikan asin tersebut. Selain membuat ikan asin ada juga pengusaha lainnya menggunakan cara pemasaran online, dan sedang menambah wawasan dalam penjualan online. Dan juga memberikan beberapa promo ke konsumen agar lebih tertarik untuk membeli.

Diharapkan untuk pemilik atau pengusaha Petis ikan dan ikan asin agar lebih mengutamakan pemasarannya, mengikuti pelatihan pemasaran secara online agar produk Petis Ikan atau ikan asin yang dijual lebih dikenal lagi, dan bisa menjualkan ke orang luar bukan hanya di pasarkan ke pelanggan saja. Dapat mencari tempat produksi yang lebih strategis lagi. Diusahakan untuk mencari inovasi produk baru dan mencari peluang kerja agar pendapatan tetap stabil.

Sebagai pelaku usaha, diperlukan beberapa langkah untuk dapat bertahan, perubahan arus keuangan perlu dilakukan untuk tetap dapat mempertahnkan usaha agar berkelanjutan pada kondisi sulit tentunya saat ini. Salah satu cara berempati dan menjaga komunikasi dengan pelanggan, dengan kondisi saat ini sangat penting menjaga kesehatan, secara aktif menginformasikan bahwa usaha petis ikan ini melakukan penerapan sesuai aturan pemerintah dengan mencegah virus penularan seperti penyemprotan disenfektan, pengecekan suhu pada tubuh pekerja. Hal ini dilakukan guna mempertahankan kepercayaan konsumen bahwa usaha petis ikan ini dapat dipasarkan seperti semula.

\section{Daftar Pustaka}

Ali Hasan, Marketing Bank Syariah, (Jakarta ; Ghalia Indonesia, 2010), halaman 29

Diah Ayu Kusuma Wardani, Strategi Penjualan Online Bagi Pelaku Usaha Pasca Pandemi Covid-19 Berdasarkan Pemetaan Perubahan Perilaku Konsumen, (Skripsi- Universitas Atma Jaya Yogyakarta, 2020)

Dr. M. Anang Firmansyah, PEMASARAN (Dasar dan Konsep), (Surabaya : Qiara Media, Tahun 2019) halaman 2

Dr. Sandu Siyoto, SKM., M.Kes \& M. Ali Sodik, M.A., Dasar Metodologi Penelitian, (Yogyakarta: Literasi Media Publishing,2015) Halaman 7578

Drs. Salim, M.Pd \& Drs. Syahrum, M.Pd, Metodologi Penelitian Kualitatif (Bandung

:Citapustaka media, 2012) 114

Dwitya Yonathan \& Lasmono Tri Sunaryanto, Strategi Ketahanan Usaha Kopi Babah Kacamata, (SkripsiUniversitas Kristen Satya Wacana, 2019)

Ellen Yuliani Saul, Strategi Bersaing Dan Strategi Bertahan Pada Industri Mikro Dan Kecil Bakpia Pathok Di Kecamatan Ngampilan Yogyakarta 
Tahun 2015, (Skripsi- Universitas Atma Jaya Yogyakarta, 2015)

Fandy Tjiptono, Strategi Pemasaran, (Yogyakarta; CV. Andi Affset, 2018) halaman 3 halaman 7.

Hitt Michael dkk, Manajemen Strategis, (Jakarta ; Airlangga, 1997), halaman 137

https://kbbi.kemendikbud.go.id/entri/ usaha diakses 7 Maret 2021

Ida Wahidah dkk, Pandemik Covid-19 : Analisis Perencanaan Pemerintah dan Masyarkat dalam Berbagai Upaya Pencegahan. Jurnal Manajemen dan Organisasi (JMO) Vol 11 No. 3 , Desember 2020, halaman 183-185

Ilham Akhsanu Ridho, Pandemi Covid-19 dan Tantangan Kebijakan Kesehatan Mental Indonesia, INSAN Jurnal Psikologi dan Kesehatan Mental, halaman 1

Mahyudin Damis, "Strategi Kebertahanan Usaha Warung Kopi Tikala Manado Tinjauan Antropologi”, Holitik, Tahun XI No.21A Januari 2018, Halaman 6

Mia Muliyani Petri, Strategi Pemasaran Dalam Mempertahankan Bisnis UMKM Di Tengah Pandemi Covid19(Studi UMKM Buket Bunga Gallery Daisuki Jambi), (SkripsiUniversitas Islam Negeri Sulthan Thaha Saifuddin Jambi, 2020)

Moh. Nazir, Metode Penelitian (Jakarta : Ghalia Indonesia, 1988) halaman 51.

Muhammad Fitrah Alghozi, Strategi Bertahan UMKM Di Masa Pandemi Covid-19 Menggunakan Metode Swot (Studi Kasus Pada Dinas Koperasi dan UKM Kota Palembang di Kecamatan Kemuning),(Skripsi-Universitas Muhammadiyah Palembang, 2021)

Prof. Dr. Conny R. Semiawan, Metode Penelitian Kualitatif (Jenis Karakteristik dan Keunggulan), (Grasindo)

R Soedijon, Metode Riset Bisnis, (Jakarta : Universitas Gunadarma, 2008)
Halaman 78 Sugiyono, Metode Penelitian Kualitatif, Kualitatif dan

R\&B (Bandung: Alfabeta: 2016) halaman 9.

Titik Rahmadiyanti, dkk, Penerapan Kebiasaan Baru Dalam Pencegahan Persebaran Pandemi Covid-19 Pada Masyarakat Melalui Media Sosial, halaman $1 \& 5$

Usman Riance Abdi, Metodologi Penelitian : Sosial dan Ekonomi Teori dan Aplikasi (Bandung: CV Alfabeta, 2009) halaman 245. 